\title{
APLIKASI BUSINES INTELLIGENCE DENGAN KONSEP OLAP PADA JURUSAN TEKNIK INFORMATIKA UPN "VETERAN" YOGYAKARTA
}

\author{
I G N Alit Widana P \\ Prodi Teknik Informatika,Fakultas IKST, Universitas Dhyana Pura, Badung - Bali \\ alit_wp@yahoo.com
}

\begin{abstract}
OLAP (Online Analytical Processing) is an special method to the analysis to data which is there are in storage media data (database) and later; then make its report according to request user. OLAP present the data in the form of easier multidimensional database to be presented and analysed. Result of analysis use the OLAP will be used in an strategic and tactical decision making in an education institute. One of them is majors of Industrial Technique Informatika Faculty Of Technology [of] UPN "veteran" Yogyakarta which can use the OLAP to the analysis to student data. use of Method OLAP majors of Industrial Technique Informatika Faculty Of Technology UPN" veteran" Yogyakarta intended to yield an application of business of analysing of student data activity of data analysing can become accurate and quicker so that support precisely decision taken by manajerial institute the education.

At this skripsi have earned made by an business application to do the analysis of student data by using method OLAP. Method used in scheme and this application making is method waterfall, by using Ianguage of pemrograman Borland Delphi 7, database Mysql, and Contourcube Activex as component OLAP.

This Application can the analysis to student data from various viewpoint of pursuant to existing dimension in application that is eye kuliah, assess the, semester, dosen, last grad by time is dimension-nya is generation and also sum up the student of per generation as measure, later result of its analysis can be made by as including for manager as this application consumer to take decision.
\end{abstract}

Key Words : OLAP (OnLine Analytical Processing), Contourcube ActiveX, dimension, time dimension, measure.

\section{ABSTRAK}

OLAP (OnLine Analytical Processing) adalah suatu metode khusus untuk melakukan analisis terhadap data yang terdapat di dalam media penyimpanan data (database) dan kemudian membuat laporannya sesuai permintaan user. OLAP menyajikan data dalam bentuk multidimensional database yang lebih mudah untuk disajikan dan dianalisis. Hasil analisis menggunakan OLAP akan digunakan dalam suatu pengambilan keputusan taktis dan strategis dalam suatu lembaga pendidikan. Salah satunya pada jurusan Teknik Informatika Fakultas Teknologi Industri UPN "veteran" Yogyakarta yang dapat menggunakan OLAP untuk melakukan analisis terhadap data mahasiswa. Penggunaan metode OLAP pada jurusan Teknik Informatika Fakultas Teknologi Industri UPN "veteran" Yogyakarta dimaksudkan untuk menghasilkan suatu aplikasi bisnis penganalisaan data mahasiswa agar kegiatan penganalisaan data dapat menjadi lebih cepat dan akurat sehingga menunjang tepatnya keputusan yang diambil oleh manajerial lembaga pendidikan.

Pada skripsi ini telah dapat dibuat suatu aplikasi bisnis untuk melakukan analisa data mahasiswa dengan menggunakan metode OLAP. Metode yang digunakan dalam perancangan dan pembuatan aplikasi ini adalah metode waterfall, dengan menggunakan bahasa pemrograman Borland Delphi 7, database MySQL, dan Contourcube ActiveX sebagai komponen OLAP.

Aplikasi ini dapat melakukan analisa terhadap data mahasiswa dari berbagai sudut pandang berdasarkan dimension yang ada dalam aplikasi yaitu mata kuliah, nilai, semester, dosen, lulusan terakhir dengan time dimension-nya adalah angkatan serta jumlah mahasiswa per angkatan sebagai measure, yang kemudian hasil analisanya dapat dijadikan sebagai masukkan bagi manajer selaku pengguna aplikasi ini untuk mengambil keputusan.

Kata Kunci : OLAP (OnLine Analytical Processing), Contourcube ActiveX, dimension, time dimension, measure. 


\section{PENDAHULUAN}

Perkembangan teknologi database saat ini sangat pesat, banyak bentuk-bentuk yang dulu hanya mempunyai teknologi sebagai tempat penyimpanan data yang terdiri dari field-field, record dan diolah serta ditampilkan menjadi informasi dalam berbagai format tampilan yang sederhana, namun kini bermula dari bentuk yang sederhana tersebut telah didapatkan suatu metode untuk menampilkan suatu database yang berguna untuk menganalisa data untuk suatu keperluan tertentu. Dengan memanfaatkan relational database yang sudah ada maka didapat suatu cara untuk mengantisipasi kebutuhan guna menganalisa data secara cepat untuk membantu mendapatkan keputusan dalam suatu organisasi.

Metode yang dimaksud tersebut adalah OLAP (OnLine Analytical Processing) yang merupakan bagian dari Data warehousing yang mendukung Business Intelligence. OLAP menggambarkan sebuah kelas teknologi yang dirancang untuk analisa dan akses data secara khusus. Apabila pada proses transaksi pada umumnya semata-mata adalah pada relational database, OLAP muncul dengan sebuah cara pandang multidimension data. Cara pandang multidimension ini didukung oleh teknologi multidimensional database. Multidimensional database mempunyai konsep dimensi, hierarki, level, dan anggota yang merupakan suatu cube atau kubus yang mempunyai hubungan struktur diantaranya. Metode ini cukup baik dipergunakan pada data yang dapat dibuat suatu agregat data yang menghasilkan bentuk keluaran berupa kalkulasi untuk sebuah aplikasi bisnis yang menganalisa data guna mendukung keputusan.

Pada saat ini sistem analisa data pada jurusan Teknik Informatika Fakultas Teknologi Industri UPN "veteran" Yogyakarta masih belum mengimplementasikan konsep OLAP. Hal ini tentunya memberikan kesulitan dalam penganalisaan data yang dari tahun ke tahun akan terus bertambah. Banyaknya data yang dianalisis menyebabkan hasil analisa terkadang kurang tepat yang tentunya menyebabkan kurang tepatnya pula pengambilan keputusan yang diperoleh dari hasil analisa tersebut.

Oleh karena itu, dibutuhkan suatu aplikasi bisnis yang menerapkan metode OLAP untuk membantu penganalisaan data sehingga dapat menghemat waktu dan menghasilkan perhi-tungan yang lebih tepat. Dengan demikian, diharapkan aplikasi tersebut dapat mempermudah lembaga pendidikan dalam mengambil keputusan sehingga tujuan dapat tercapai.

\section{LANDASAN TEORI}

\section{DATA WAREHOUSE}

Data warehouse adalah basis data yang menyimpan data sekarang dan data masa lalu yang berasal dari berbagai system operasional dan sumber yang lain (sumber eksternal) yang menjadi perhatian penting bagi manajemen dalam organisasi dan ditujukan untuk keperluan analisis dan pelaporan manajemen dalam rangka pengambilan keputusan (Kadir, 2003).

Data warehouse digunakan untuk mendukung pengambilan keputusan, bukan untuk melaksanakan pemrosesan transaksi. Data warehouse memiliki karakteristik sebagai berikut (Hermawan, 2005) : (1) Data dikumpulkan dari sumber - sumber lain seperti sistem lama ataupun system OLTP. (2) Data dibuat konsisten dengan penyimpanan di data warehouse. (3) Data diringkas. Data warehouse umumnya tidak menyimpan serinci system berorientasi transaksi.(4) Data berumur lebih lama. System transaksi dapat mempertahankan data hanya sampai selesainya transaksi, sedangkan data warehouse dapat mempertahankan data sampai bertahun - tahun. (5) Data disimpan dalam suatu format yang nyaman untuk melakukan query dan analisis. (6) Data biasanya read only.

\section{METODE OLAP (On-Line Analytical Processing) \\ OLAP singkatan dari On-Line Analy-} tical Processing. Secara mendasar OLAP adalah suatu metode khusus untuk melakukan analisis terhadap data yang terdapat di dalam media penyimpanan data (database) dan kemudian membuat laporannya sesuai dengan permintaan user. Untuk tujuan tersebut data yang berupa informasi dibuat dalam format khusus dengan memberikan group terhadap data (Hermawan, 2005).

OLAP menampilkan data dalam sebuah tabel yang dinamis, yang secara otomatis akan meringkas data ke dalam beberapa irisan data yang berbeda dan mengizinkan user untuk secara interaktif melakukan perhitungan serta membuat format suatu laporan. Tool untuk membuat laporan adalah tabel itu sendiri, yaitu dengan melakukan drag terhadap kolom dan baris. User dapat mengubah bentuk laporan dan menggolongkannya sesuai dengan keinginan dan kebutuhan user, 
dan OLAP engine secara otomatis akan mengkalkulasi data yang baru (Hermawan, 2005).

Model yang digunakan dalam OLAP adalah model kubus. Model kubus akan mengelompokkan data dan parameter-parameter sehingga kita dapat merelasikan antara data yang satu dengan data yang lain sehingga membentuk suatu pengertian khusus.

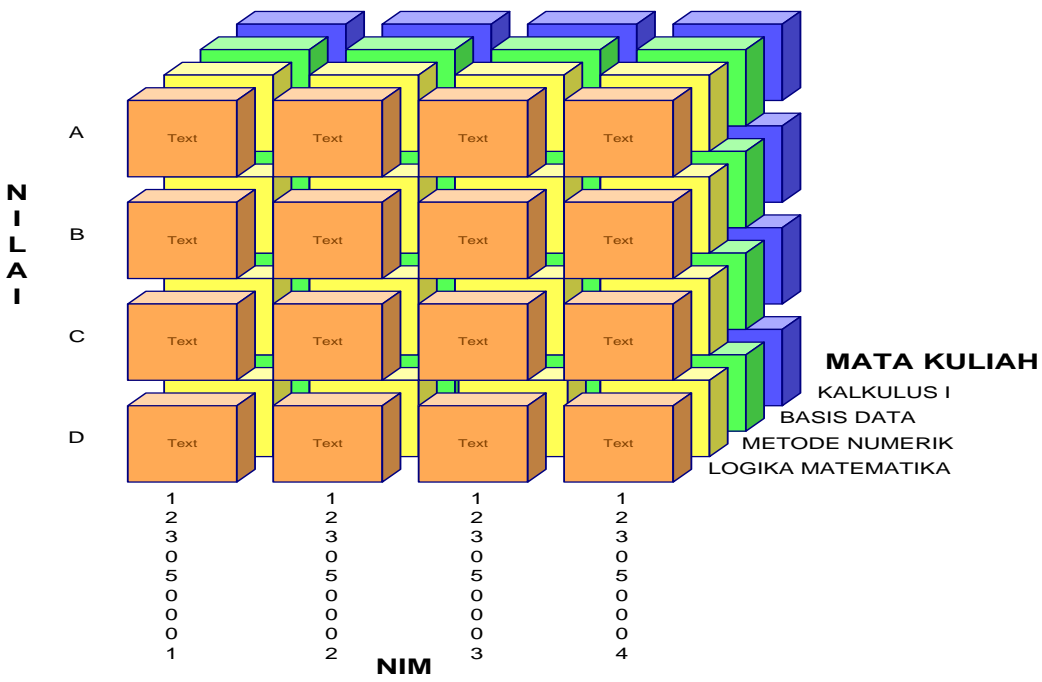

Gambar 1. Model Kubus

Secara terminologi, sebuah kubus terdiri dari tiga komponen, seperti kubus yang memiliki tiga sisi. Ketiga komponen tersebut adalah (Hermawan, 2005) :

Dimension, adalah sebuah garis atau poros yang berlawanan dengan figure yang akan ditampilkan. Sebagai dimensi dalam sebuah teknologi OLAP, kubus secara hierarki terdiri dari parent-child yang mana relasi child mendukung level parent.

Time Dimension, adalah tipe spesial dari dimensi yang didefinisikan sebagai the time detail dari sebuah kubus, yang secara normal di dalam kubus didefinisikan sebagai main axis. Kalkulasi yang spesifik, termasuk perputaran dari rata-rata dalam tahun ke tanggal hanya akan bekerja jika dimensi waktu didefinisikan. Time dimension ini dapat bertukar-tukar dari model ke model dan dapat berubah dari level tahun ke level menit.

Measure, adalah sebuah entitas yang dapat dimonitor dan diukur dari dimensi. Secara mendasar measure dimuat ke dalam OLAP database. Menghitung measure adalah menghitung dari measure dasar sehingga untuk itu tidak perlu dimasukkan ke dalam source data. 


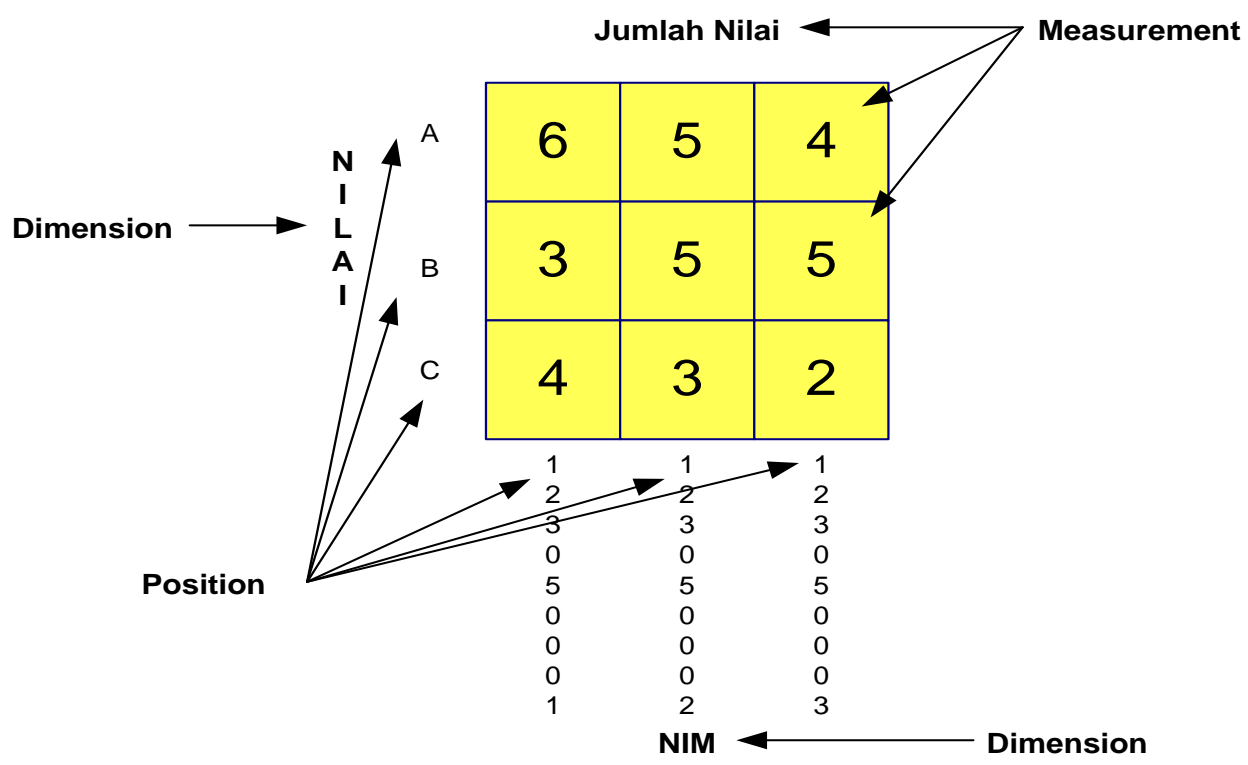

Gambar 2. Array Multidimensi

\section{METODOLOGI PENGEMBANGAN SISTEM}

Metodologi pengembangan sistem yang digunakan adalah model sekuensial linier atau sering disebut juga siklus kehidupan klasik atau model air terjun. Model air terjun mengusulkan sebuah pendekatan kepada perkembangan perangkat lunak yang sistematik dan sekuensial yang mulai pada tingkat dan kemajuan sistem pada seluruh analisis, desain, kode, pengujian, dan pemeliharaan. Model air terjun melingkupi aktivitas - aktivitas sebagai berikut (Pressman, 2002):

\section{Rekayasa dan pemodelan sistem / infor- masi.}

Karena perangkat lunak selalu merupakan bagian dari sebuah sistem yang lebih besar, kerja dimulai dengan membangun syarat dari semua elemen sistem dan mengalokasikan beberapa subset dari kebutuhan ke perangkat lunak tersebut. Pandangan sistem ini penting ketika perangkat lunak harus berhubungan dengan elemenelemen yang lain seperti perangkat lunak, manusia, dan database. Rekayasa dan analisis sistem menyangkut pengumpulan kebutuhan pada tingkat sistem dengan sejumlah kecil analisis serta desain tingkat puncak. Rekayasa informasi menyangkut juga pengumpulan kebutuhan pada tingkat bisnis strategis dan tingkat area bisnis.
Analisis kebutuhan perangkat lunak.

Proses pengumpulan kebutuhan diintensifkan dan difokuskan, khususnya pada perangkat lunak. Untuk memahami sifat program yang dibangun, analis harus memahami domain informasi, tingkah laku, unjuk kerja, dan antar-muka yang diperlukan. Kebutuhan baik untuk sistem maupun perangkat lunak didokumentasikan dan dilihat lagi dengan pelanggan.

\section{Desain}

Design perangkat lunak sebenarnya adalah proses multi langkah yang berfokus pada empat atribut sebuah program yang berbeda, struktur data, arsitektur perangkat lunak, representasi interface dan algoritma prosedural. Proses desain menerjemahkan syarat/kebutuhan ke dalam representasi perangkat lunak yang dapat diperkirakan demi kualitas sebelum dimulai pemunculan kode. Sebagaimana persyaratan, desain didokumentasikan dan menjadi bagian dari konfigurasi perangkat lunak.

\section{Membuat Kode.}

Desain harus diterjemahkan ke dalam bentuk mesin yang bisa dibaca. Langkah pembuatan kode melakukan tugas ini. Jika desain dilakukan dengan cara yang lengkap, pembuatan kode dapat diselesaikan secara mekanis. 


\section{Pengujian.}

Sekali kode dibuat, pengujian program dimulai. Proses pengujian berfokus pada logika internal perangkat lunak, memastikan bahwa semua pernyataan sudah diuji, dan pada eksternal fungsional yaitu mengarahkan pengujian untuk menemukan kesalahan-kesalahan dan memastikan bahwa input yang dibatasi akan memberikan hasil aktual yang sesuai dengan hasil yang dibutuhkan.

\section{Pemeliharaan}

Perangkat lunak untuk mengalami perubahan setelah disampaikan kepada pelanggan. Perubahan akan terjadi karena kesalahan-kesalahan ditentukan, karena perangkat lunak harus disesuaikan untuk mengakomodasi perubahan-perubahan di dalam lingkungan eksternalnya (contohnya perubahan yang dibutuhkan sebagai akibat dari perangkat peripheral atau sistem operasi yang baru) atau karena pelanggan membutuhkan perkembangan fungsional atau un- juk kerja. Pemeliharaan perangkat lunak mengaplikasikan lagi setiap fase program sebelumnya dan tidak membuat yang baru lagi.

\section{ANALISIS DAN PERANCANGAN}

Dalam DFD Analisa Data Mahasiswa ini terdapat lima table yaitu table dosen, table identitas_siswa, table mata_kuliah, table nilai, dan table login. Pada DFD Analisa Data Mahasiswa ini terdapat 8 proses. Proses pada user adalah proses ekstraksi data yang diinputkan oleh CBIS yang kemudian akan dilanjutkan ke proses pengumpulan data ekstraksi, proses cetak laporan, proses export data, dan proses login. Karena proses cetak laporan dan export data mengambil data dari hasil analisa maka, proses ini dapat dilakukan jika user sudah melalui proses pengumpulan data ekstraksi. Proses tersebut dapat digambarkan seperti pada gambar 3 .

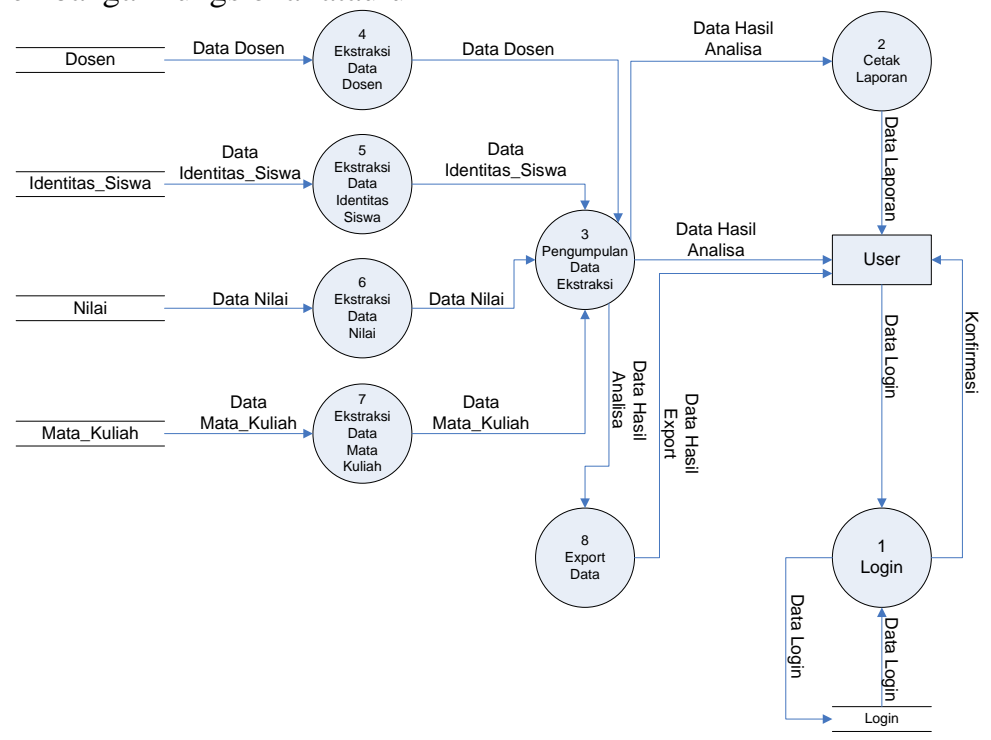

\section{Gambar 3. DFD Analisa Data Mahasiswa}

Diagram hubungan antar entitas pada perancangan aplikasi bisnis penganalisaan data mahasiswa ini memiliki enam buah tabel yang saling berhubungan. Berikut adalah gambar diagram ERD pada gambar 4. 


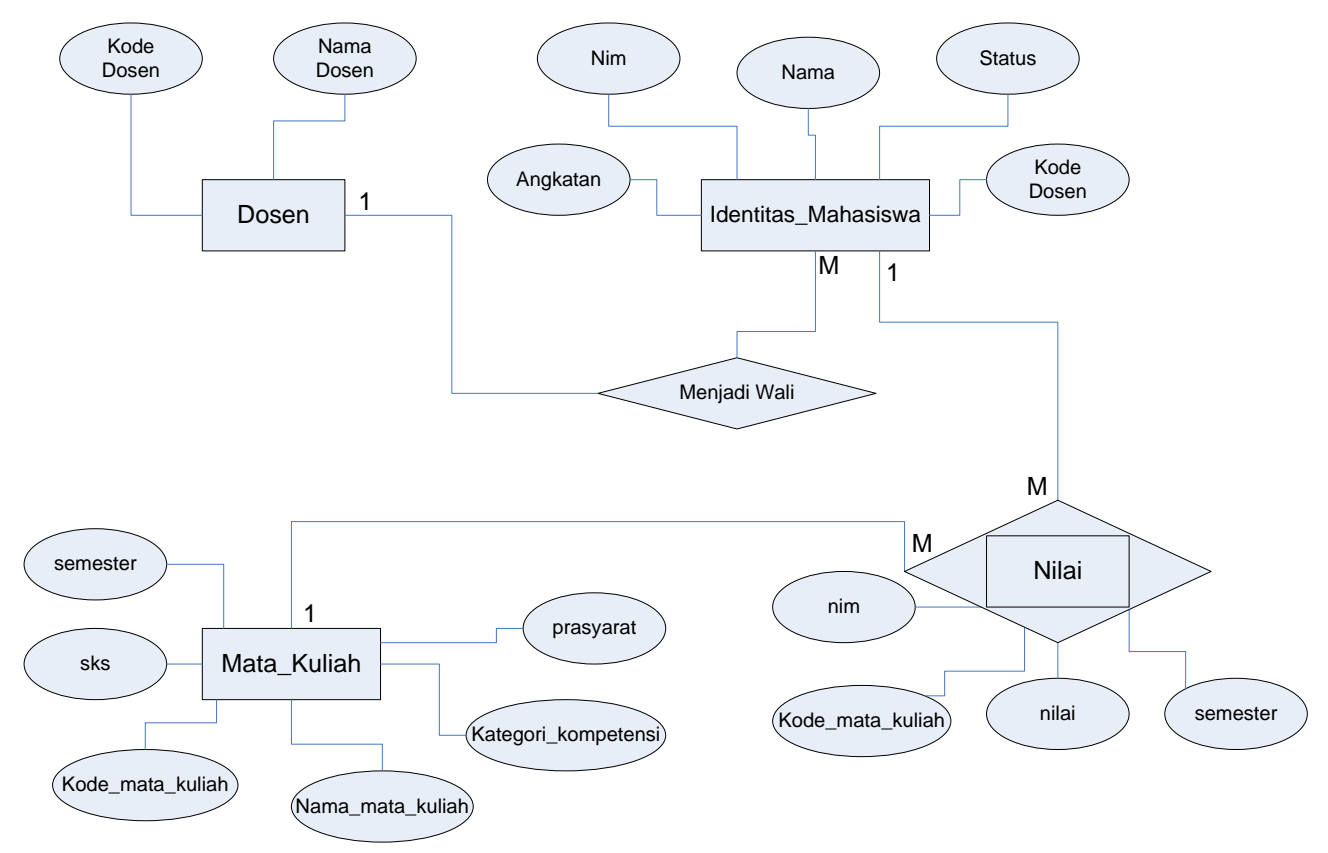

Gambar 4. ERD Analisa Data Mahasiswa

\section{IMPLEMENTASI}

Pada form analisis, disini dilakukan proses analisa data mahasiswa. User dapat memilih sebelum melakukan analisa. Disediakan dua bentuk analisa yaitu analisa sks dan analisa ipk. Setelah user memilih salah satu bentuk analisis maka akan muncul sebuah grid. Pada grid tersebut terdapat dimensi-dimensi. Dimensi yang terlihat samar-samar adalah dimensi yang tidak aktif. User dapat melakukan drill up dan drill down terhadap dimensi yang sudah ada serta melakukan filtering data sesuai kebutuhan user. Maka akan diperoleh hasil yang bervariasi. Pada saat grid aktif maka terdapat beberapa tombol pada toolbar yang ikut aktif yaitu : swap, collapse, expand, percents, sortbyrows, sortbycols, scale, hfilter, export to html, export to excel, export to word, dan print. Hasil aplikasi analisa data mahasiswa dapat dilihat pada gambar 5 dan gambar 6 .

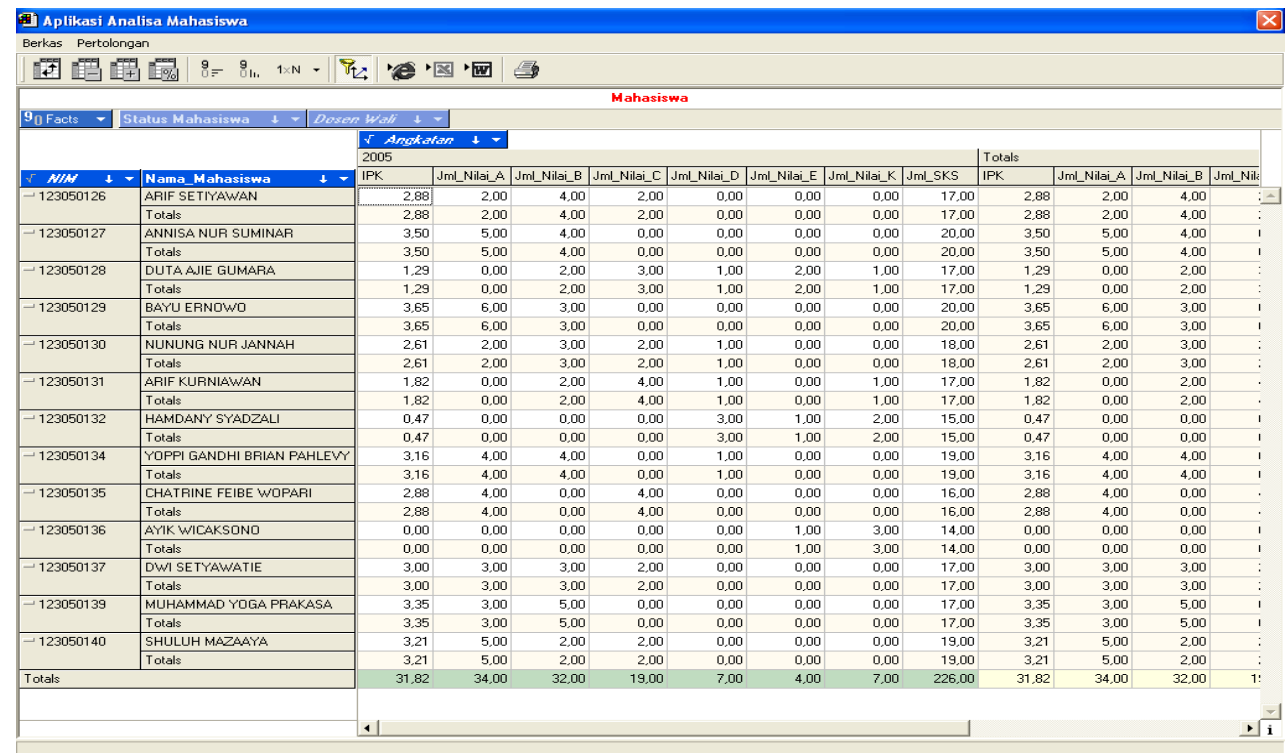

Gambar 5. Form Analisa 


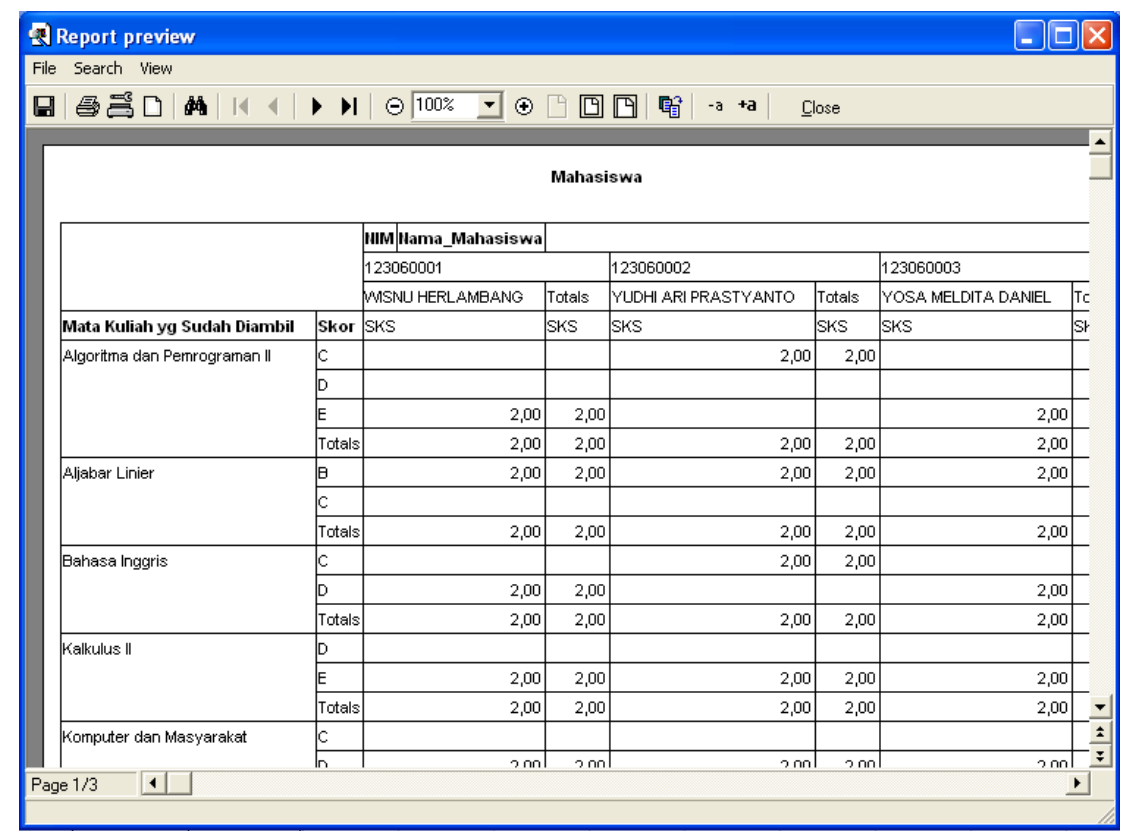

Gambar 6. Cetak Laporan

\section{SIMPULAN}

Dapat diambil kesimpulan dari penjelasan dan uraian bab-bab sebelumnya, bahwa telah dirancang dan dibangun aplikasi kecerdasan bisnis dengan konsep OLAP pada jurusan teknik informatika UPN "veteran" Yogyakarta yang dapat membantu mendapatkan informasi secara cepat dan tepat dengan penjelasan sebagai berikut :

Telah dapat dihasilkan suatu produk yaitu aplikasi kecerdasan bisnis dengan konsep OLAP pada jurusan teknik informatika yang dapat menganalisis data mahasiswa yaitu analisis sks dan analisis ipk. Hasil ini menjawab bahwa tujuan penelitian telah tercapai.

Dari evaluasi software oleh pengguna sistem telah memenuhi kriteria baik untuk kategori user friendly, user interface, laporan, input/output, efektif dan efisien.

\section{DAFTAR PUSTAKA}

[1] Hartono Jogiyanto, MBA, Ph.D., 1999, Pengenalan Komputer, Andi, Yogyakarta

[2] Herry Sofyan.,Budi Santosa, HandOut Sistem Basis Data, Jurusan Teknik Informatika.
[3] Husni, 2004, Pemrograman Database Dengan Delphi, Graha Ilmu, Yogyakarta.

[4] Http://www. wikipedi.com/

[5] Kadir Abdul, 2003, Konsep dan Tuntunan Praktis Basis Data. Andi, Yogyakarta.

[6] Kadir Abdul, 2003, Pengenalan Sistem Informasi. Andi, Yogyakarta.

[7] Pressman Roger S, Ph.D., 2002, Rekayasa Perangkat Lunak Pendekatan Praktisi (Buku Satu), Andi, Yogyakarta.

[8] Yudhi Hermawan, 2005, Konsep OLAP dan Aplikasinya Menggunakan Delphi, Andi, Yogyakarta.

[9] Wahana Komputer, 2003, Pengembangan Aplikasi Client/Server dengan Borland Delphi, Elex Media Komputindo, Jakarta.

[10] Wahana Komputer, 2005, Membuat Program Kreatif dan Profesional dengan Delphi, Elex Media Komputindo, Jakarta. 